\title{
PARADIGMA HUKUM WARIS ATAS TANAH YANG TIDAK MENGENAL DALUARSA SETELAH TERBITNYA UUPA
}

\author{
Andreas J Sinaga \\ Fakultas Hukum Universitas Katolik Santo Thomas, Medan Indonesia \\ Email : andreas_sinaga@ust.ac.id
}

\begin{abstract}
ABSTRAK
Dalam berperkara di Pengadilan biasanya Tergugat membuat eksepsi mengenai kadaluarsa verjaring hak menggugat yang dikenal dengan istilah Exeptio Temporis. Dalam hukum waris KUHPerdata mengatur mengenai lewat waktu verjaring yaitu, Pasal 835 Tuntutan itu (ahli waris berhak mengajukan gugatan untuk memperoleh warisannya terhadap semua orang yang menguasai seluruh atau sebagian warisan itu dengan alas hak ataupun tanpa alas hak) menjadi lewat waktu dengan lewatnya waktu tiga puluh tahun, terhitung dan hari terbukanya warisan itu. Munculnya Undang-Undang Nomor 5 Tahun 1960 Tentang Peraturan Dasar Pokok-Pokok Agraria menghapus dualisme sepanjang mengenai tanah dengan berlakunya hukum adat disamping hukum agraria yang didasarkan atas KUHPerdata, sehingga UUPA tersebut mencabut buku ke II KUHPerdata sepanjang mengenai bumi, air serta kekayaan alam yang terkandung didalamnya karena UUPA mangakomodasi hukum adat.
\end{abstract}

\section{Kata Kunci : Hukum Waris, Verjaring, UUPA}

\begin{abstract}
In litigating in the court, the Defendant usually made an exception regarding the expiration of the suing rights verjaring, known as Exeptio Temporis. In the inheritance law the Civil Code regulates the passing of verjaring, Article $835 \mathrm{BW}$ That claim (heirs has the right to submit a claim to obtain his inheritance against all people who control all or part of the inheritance on the basis of rights or without basis of rights) becomes past due with the passage of thirty year, counted and the day the inheritance was opened. The emergence of Undang-Undang Nomor 5 Tahun 1960 Tentang Peraturan Dasar Pokok-Pokok Agraria (Law of Basic Rules of Agrarian Principles) eradicates dualism as long as land is enforced with customary law in addition to agrarian law based on the Civil Code, so the Law of Basic Rules of Agrarian Principles revokes the second book of the Civil Code as long as it concerns the earth, water and natural resources that contained therein because the Law of Basic Rules of Agrarian Principles accommodates customary law.
\end{abstract}

Keywords: Inheritance Law, Verjaring, UUPA

Paradigma Hukum Waris Atas Tanah Yang Tidak Mengenal Daluarsa Setelah Terbitnya UUPA

Oleh Andreas J Sinaga 


\section{A. PENDAHULUAN}

Sistem hukum kewarisan di Indonesia masih diatur dalam berbagai peraturan perundangan-undangan yang berlaku. Hukum waris yang diatur dalam KUHP Perdata masih berlaku sebagai pedoman bagi beberapa masyarakat. Untuk yang beragama Islam juga menggunakan hukum Islam sebagai dasar untuk membagi maupun menggugat harta warisan, kemudian untuk masyarakat adat yang masih mengikuti pola-pola kemasyarakatan tertentu menggunakan hukum Adat yang tidak tertulis. Dasar hukum berlakunya hukum adat telah dimotori dalam pasal 131 I.S (Indische Staatssregeling) ayat 2b (Stb 1925 no.415 jo.577), termasuk juga berlakunya hukum waris adat yaitu bagi golongan Indonesia asli (Bumi Putra), golongan Timur Asing dan bagian-bagian dari golongan bangsa tersebut, berlaku peraturan hukum yang didasarkan atas agama dan kebiasaan mereka.UndangUndang Dasar 1945 Pasal 18 B ayat (2) menyatakan Negara mengakui dan menghormati kesatuan-kesatuan sosial masyarakat hukum adat beserta hak-hak tradisionalnya sepanjang masih hidup sesuai dengan perkembangan masyarakat, dan prinsip Negara Kesatuan Republik Indonesia yang diatur dalam UndangUndang. Hal ini senada dengan pendapat Soepomo "Hakim, menurut fungsinya, berwenang bahkan wajib mempertimbangkan, apakah peraturan Hukum Adat yang telah ada yang mengenai soal yang dihadapi, masih selaras atau sudah bertentangan dengan kenyataan sosial sociale werlijkheid baru berhubungan dengan pertumbuhan situasi baru didalam masyarakat. ${ }^{1}$

Munculnya Undang-Undang Nomor 5 Tahun 1960 Tentang Peraturan Dasar Pokok-Pokok Agraria menghapus dualisme sepanjang mengenai tanah dengan berlakunya hukum adat disamping hukum agraria yang didasarkan atas KUHPerdata, sehingga UU PA tersebut mencabut buku ke II KUHPerdata sepanjang mengenai bumi, air serta kekayaan alam yang terkandung didalamnya karena UUPA mangakomodasi hukum adat. Namun tidak menegaskan mengenai jangka waktu membagi harta warisan yang menyangkut tanah yang terdapat dalam

\footnotetext{
${ }^{1}$ Soedarso, 2014, Hukum Adat Waris, didalam buku Eksistensi Pengadilan Adat Dalam Sistem Peradilan Adat Di Indonesia, Herowati Poesok et all, LaksBang Justitia, Surabaya, hlm. 20.

Paradigma Hukum Waris Atas Tanah Yang Tidak Mengenal Daluarsa Setelah Terbitnya UUPA

Oleh Andreas J Sinaga 
Pasal 835 buku ke III KUHPerdata, sehingga yang berlaku adalah hukum adat yang tidak megenal kadaluarsa (verjaring) dan Pasal 1967 KUHPer yang berbunyi : "Semua tuntutan hukum, baik yang bersifat kebendaan maupun yang bersifat perorangan, hapus karena lewat waktu tiga puluh tahun, sedangkan orang yang menunjuk adanya lewat waktu, tidak usah menunjukkan suatu alas hak, dan terhadapnya tak dapat diajukan suatu tangkisan yang didasarkan pada itikad buruk." Masalah lainnya munculnya Lembaga rechtverwerking yang dituangkan dalam Pasal 32 ayat (2) PP Nomor 24 tahun 1997 Tentang Pendaftaran Tanah dikenal dalam hukum adat dan yurisprudensi yaitu bagaimana lembaga rechtverwerking ini dapat mengatasi kelemahan-kelemahan sistem publikasi negatif dan penerapan hakim dalam menyelesaikan sengketa tanah terkait dengan adanya gugatan dari pihak yang merasa berhak atas suatu tanah yang secara fisik telah dikuasai oleh orang lain dengan bukti yuridis berupa sertifikat hak atas tanah. Dalam arti lain bahwa hak milik, hak guna usaha, hak guna bangunan dapat hapus atau kehilangan haknya karena dalam waktu 5 (lima) tahun sejak diterbitkannya sertifikat itu tidak mangajukan keberatan secara tertulis kepada pemegnag sertifikat dan Kepala Kantor Pertanahan yang bersangkutan ataupun tidak mengajukan gugatan ke Pengadilan mengenai penguasaan tanah atau penerbitan sertifikat tersebut.

Menurut peraturan-peraturan berikut ini dan terkhusus pada masalah yang dibahas yaitu mengenai jangka waktu hak menggugat harta warisan. Dalam berperkara di Pengadilan Tergugat biasanya membuat eksepsi mengenai kadaluarsa verjaring hak menggugat yang dikenal dengan istilah Exeptio Temporis. Dalam hukum waris KUHPerdata mengatur mengenai lewat waktu verjaring yaitu, Pasal 835 Tuntutan itu (ahli waris berhak mengajukan gugatan untuk memperoleh warisannya terhadap semua orang yang menguasai seluruh atau sebagian warisan itu dengan alas hak ataupun tanpa alas hak) menjadi lewat waktu dengan lewatnya waktu tiga puluh tahun, terhitung dan hari terbukanya warisan itu. Masalah jangka waktu hak menggugat harta warisan memang menarik untuk diteliti, apabila harta warisan sudah terbuka atau yang dikenal dengan boedel warisan, ahli waris berhak mengajukan gugatan untuk memperoleh warisannya terhadap semua orang yang memegang besit (menguasasi) atas seluruh atau sebagian warisan itu dengan alas hak ataupun tanpa alas hak namun setelah lewat 30 (tiga puluh tahun) lamanya, Paradigma Hukum Waris Atas Tanah Yang Tidak Mengenal Daluarsa Setelah Terbitnya UUPA 
harta warisan tersebut belum dibagikan. Dalam KUHPerdata mengenal kadaluarsa verjaring, sedangkan ketentuan hukum adat sendiri tidak mengenal kadaluarsa dalam pembagian harta warisan. Kasus terbaru yang berkaitan dengan jangka waktu hak menggugat harta warisan masyarakat adalah Perkara gugatan harta warisan Reg, No.32/Pdt.G/2019/PN. Lubuk Pakam. Penggugat yaitu Saut Maruli Manurung, Mangatur Manurung dan Hiras Br. Sitorus melawan Tiarma Br. Sitorus. Kasus ini menceritakan diamana Harta warisan yang terbuka belum pernah dibagi dan telah dikuasai dan disertifikatkan atas nama Tergugat sampai saat ini, lamanya sudah lebih 40 tahun.

Penelitian ini mendorong agar mengetahui paradigma dan hak fundamental yang terdapat di dalam nilai kemasyarakatan diaktualisasikan ke dalam konsep dan praktik hak menggugat harta warisan masyarakat adat dengan lewatnya waktu 30 tahun atau kadaluarsa verjaring sedangkan salah satu ahli waris telah menguasai, mensertifikatkan atas namanya sendiri maupun menjual boedel warisan yang belum terbagi. Dalam konteks itulah, penulis ingin mengungkap paradigma hukum waris atas tanah yang tidak mengenal kadaluarsa (verjaring) setelah terbitnya UUPA. Rumusan masalah yang dibahas yakni: (i). Bagaimanakah paradigma hukum waris atas tanah yang tidak mengenal kadaluarsa (verjaring) setelah terbitnya UUPA? (ii). Bagaimankah penerapan hukum jangka waktu hak menuntut yang terkandung dalam sistem kewarisan masyarakat adat dalam putusan pengadilan?

\section{B. METODE PENELITIAN}

Penelitian ini bersifat deskriptif yaitu data yang berbentuk uraian-uraian yang menganalisis secara sistematis, faktual, dan akurat hasil penelitian dan pembahasan tentang paradigma hukum waris atas tanah yang tidak mengenal kadaluarsa (verjaring) setelah terbitnya UUPA. Untuk melengkapi bahan dan jawaban yang kongkret, objektif, ilmiah, dan dapat dipertanggungjawabkan, penulis menggunakan metode pendekatan yuridis normatif. Dalam penulisan ini didapat sumber dari penelitian kepustakaan (library research).

Paradigma Hukum Waris Atas Tanah Yang Tidak Mengenal Daluarsa Setelah Terbitnya UUPA

Oleh Andreas J Sinaga 


\section{PEMBAHASAN}

\section{Paradigma Hukum Waris atas Tanah yang Tidak Mengenal Kadaluarsa Verjaring Setelah Terbitnya UUPA.}

Buku II KUHPer Tentang Benda yang mengatur mengenai tanah dinyatakan tidak berlaku lagi setelah terbitnya UUPA. Undang-Undang ini mengatur mengenai bumi, air, kekayaan alam dan tanah termasuk didalamnya. Hal ini dilakukan agar tercipta unifikasi hukum tanah di Indonesia, dimana tujuan dari pembentukan UUPA sendiri adalah agar terciptanya unifikasi hukum tanah nasional. Penyebab terjadinya dualisme hukum tanah di Indonesia karena dahulu hukum tanah di Indonesia sangat beragam, ada yang menggunakan hukum KUHPer dan hukum adat, sehingga harapan adanya unifikasi hukum persoalan-persoalan yang menimpang dari prinsip-prinsip tanah di Indonesia dapat diselesaikan lebih baik.

\section{a. Perolehan hak milik berdasarkan Pasal 835 KUHP Perdata setelah terbitnya UUPA}

Pasal 835 KUHPerdata adalah pasal yang mengatur syarat-syarat yang harus dipenehui seseorang agar dapat memperoleh hak milik dengan cara daluarsa atau lewat waktu. Sehingga tanah yang merupakan benda tak bergerak pun menngunakan aturan ini dahulu, sebagai dasar memperoleh hak atas tanah. Fenomena sengketa waris adat muncul akibat dari adanya pertambahan nilai dari objek waris tersebut akibat dari pengadaan tanah untuk kepentingan infrastruktur, industri, perumahan, pertanian maupun pengelolaan perkebunan. Tanah yang merupakan salah satu objek kewarisan yang menjadi sengketa dapat terjadi karena kurang jelasnya atau tumpang tindihnya peraturan perundang-undangan, khususnya dalam hal ini Undang-Undang Pokok Agraria yang awalnya merupakan sumber perlindungan hukum bagi kebijakan pertanahan di Indonesia tidak berfungsi dengan baik dan secara substansial terdapat peraturan yang kurang singkron atau mengalami pertentangan dengan peraturan sektoral, sehingga dapat mengakibatkan benturan dilapangan antara penggunaan penafsiaran UU yang berbeda dari pejabatpejabat pemerintahan yang berbeda-beda atas konflik penguasaan tanah yang sama, sehingga dapat dimungkinkan pula penguasaan yang lama atas objek warisan oleh salah satu ahli waris dapat dibuatkan ketetapan kepemilikan tanah atau pengalihan hak kepada orang lain, contohnya munculnya Surat Keputusan Bupati menjadi Paradigma Hukum Waris Atas Tanah Yang Tidak Mengenal Daluarsa Setelah Terbitnya UUPA 
milik seorang ahli waris padahal objek warisan belum pernah terbagi, pensertifikatan tanah secara sepihak tanpa diketahui oleh ahli waris lainnya.

Dalam hukum kewarisan menurut KUHPer setiap ahli waris dapat menuntut atau menggugat pembagian harta warisan tersebut sewaktu-waktu. ${ }^{2}$ Hukum waris menurut KUHPer berlandaskan pada sifat Eropa Daratan yang lebih individualis yang tidak memiliki ciri kekeluargaan. Hukum waris menurut KUHPer mengenal prinsip hukum legitime portie yaitu menyangkut besarnya pembagian pada masingmasing ahli waris telah ditentukan oleh undang-undang sebagaimana telah diatur dalam Pasal 913-929. Dalam hukum adat, harta peninggalan untuk sementara tidak dibagi atau ditunda untuk waktu yang lama bahkan hanya sebagian saja yang dibagi. Harta peninggalan tidak merupakan satu kesatuan harta warisan yang segera dibagikan, ada beberapa hal yang wajib diperhatikan dari segi sifat, macam, asal dan kedudukan hukum dari pada barang-barang masing-masing yang terdapat pada harta peninggalan tersebut. ${ }^{3}$ Dalam hukum waris adat harta warisan tidak boleh dipaksakan untuk segera dibagi di antara para ahli waris, karena perbuatan demikian dianggap tidak sesuai dengan nilai-nilai kemasyarakatan dan bertentangan dengan moral.

Pemeliharaan sementara objek warisan yang belum dibagi juga dapat dilakukan oleh salah satu ahli waris dalam jangka waktu yang sangat lama sampai munculnya kesepakantan bersama pembagian objek waris. ${ }^{4}$ Pemeliharaan sementara objek warisan yang dikuasai, ditempati maupun diolah orang salah satu ahli waris bukan menyebabkan beralihnya kepemilikan dan juga bukan menjadi leluasa atau sewenang-wenang ahli waris yang mengusai sementara objek warisan tersebut bahkan bukan menyebabkan ahli warisnya lainnya tidak menelantarkan atau tidak memelihara objek warisan yang belum sama sekali terbagi tersebut. Penguasaan/pemeliharaan sementara ini dimaksudkan agar hak pakai, hak mengelolah, dan hak memungut hasilnya dikuasai oleh salah satu ahli waris dengan

\footnotetext{
${ }^{2}$ Dominikus Rato, 2015, Hukum Perkawinan dan Waris Adat di Indonesia, Laksbang, Yogyakarta, hlm. 112

${ }^{3}$ Ibid, hlm. 111

${ }^{4}$ Dewi Wulansari, 2014, Hukum Adat Indonesia Suatu Pengantar, Refika Aditama, Bandung, hlm. 73 Paradigma Hukum Waris Atas Tanah Yang Tidak Mengenal Daluarsa Setelah Terbitnya UUPA

Oleh Andreas J Sinaga 
hak dan kewajiban mengurus dan memelihara adik-adiknya yang laki-laki maupun perempuan hingga mereka hidup mandiri.

Pengaturan seperti yang terdapat dalam Pasal 830 KUHPer tentang perolehan hak milik berdasarkan lewat waktu dapat ditemukan dalam Peraturan Pelaksana dari UUPA Nomor 24 tahun 1997 Tentang Pendaftaran Tanah, pada pasal 24 ayat 2 yang mengatakan "selama 20 (dua puluh) tahun atau lebih secara berturut-turut oleh pemohon dan pendahulu-pendahulunya, dengan syarat : a. Penguasaan dilakukan dengan itikad baik dan secara terbuka oleh orang yang bersangkutan sebagai yang berhak atas tanah, serta diperkuat dengan kesaksian orang yang dapat dipercaya, b.Penguasaan tersebut sebagaimana yang dimaskud dalan Pasal 26 tidak dipermasalahkan oleh masyarakat hukum adat atau desa/kelurahan yang bersangkutan ataupun pihak lainnya

Pasal 32 ayat (2) Peraturan Pemerintah Republik Indonesia Nomor 24 Tahun 1997 Tentang Pendaftaran Tanah mengatakan "Dalam hal atas suatu bidang tanah sudah diterbitkan sertifikat secara sah atas nama orang atau badan hukum yang memperoleh tanah tersebut dengan itikad baik dan secara nyata menguasainya, maka pihak lain yang merasa mempunyai hak atas tanah itu tidak dapat lagi menuntut pelaksanaan hak tersebut apabila dalam waktu 5 (lima) tahun sejak diterbitkannya sertifikat itu tidak mengajukan keberatan secara tertulis kepada pemegang sertifikat dan Kepala Kantor Pertanahan yang bersangkutan ataupun tidak mengajukan gugatan ke Pengadilan mengenai penguasaan tanah atu penerbitan sertifikat tersebut". Itikad baik yang dimaksud misalnya ialah menjaga kondisi tanah, pembayar PBB, merawat atau mengelola tanah tersebut. Apabila seseorang hendak melakukan gugatan terhadap tergugat yang telah mempunyai sertifikat telah lewat 5 tahun sesuai ketentuan Pasal 32 ayat 2 dari PP No. 24 Tahun 1997 maka penggugat biasanya tidak menggugat untuk pembatalan sertifikat melainkan berdasarkan sengketa waris maupun sengketa kepemilikan.

Namun terjadi persoalan lain apakah seorang ahli waris yang mengusai tanah tesebut selama lebih dari 30 (tiga puluh) tahun sedangkan tanah tersebut masih belum dibagikan atau masih berstatus tanah warisan, sedangkan ahli waris yang melakukan penguasan tersebut kemudian memperoleh sertifikat tanah atas namanya seorang tanpa melibatkan atau memberi tahu ahli waris lainnya dianggap Paradigma Hukum Waris Atas Tanah Yang Tidak Mengenal Daluarsa Setelah Terbitnya UUPA 
sah?. Untuk menjawab persoalan ini maka Pasal 1959 KUHPerdata menjelaskan bahwa "orang yang menguasai suatu barang untuk orang lain, begitu pula ahli warisnya, sekali-kali tidak dapat memperoleh sesuatu dengan jalan lewat waktu, berapa lama pun waktu yang telah lewat. Demikian pula seorang penyewa, seorang penyimpan, seorang penikmat hasil, dan semua orang lain yang memegang suatu barang berdasarkan suatu persetujuan dengan pemiliknya, tak dapat memperoleh barang tersebut. Meskipun terdapat ketentuan yang membatasi bahwa keberatan atau gugatan atas hak atas tanah terdaftar hanya dapat diajukan dalam jangka waktu lima tahun, namun jangka waktu ini pada prakteknya tidak mengikat. Kerena ketentuan daluarsa ini tidak berdiri sendiri melainkan mempersyaratkan adanya itikad baik yang harus ditetapkan oleh hakim, di samping bahwa sertifikat harus diterbitkan secara sah dan tanah telah dikuasai secara nyata.

\section{b. Lembaga Rechtverwerking dalam budaya hukum masyarakat adat}

Menurut KUHPer daluarsa yang berkaitan dengan jangka waktu tertentu mengakibatkan seseorang mendaptkan sesuatu acqiusitive verjaring atau dibebaskan dari suatu perikatan fokusnya adalah pada pihak yang memperoleh hak dan pada kemungkinan gugatan dari pihak lain. Meski dalam penjelasannya disebutkan bahwa PP No. 24/1997 mengadopsinya dari hukum adat nasional, rechtverwerking ynag dimaksud sesungguhnya tidak sama dengan konsep hukum adat. Dalam hukum adat, jika seseorang selama sekian waktu menelantarkan tanah maka tanah itu jatuh kembali kepada hak ulayat.

Jika ditanjau dari Lembaga rechtverwerking yang dituangkan dalam Pasal 32 ayat (2) PP Nomor 24 tahun 1997 dikenal dalan hukum adat dan Yurisprudensi yaitu bagaiman lembaga rechtverwerking ini dapat mengatasi kelemahankelemahan sistem publikasi negatif dan penerapan hakim dalam menyelesaikan sengketa tanah terkait dengan adanya gugatan dari pihak yang merasa berhak atas suatu tanah yang secara fisik telah dikuasai oleh orang lain dengan bukti yuridis berupa sertifikat hak atas tanah. Terdapat hubungan antara tanah terlantar dengan berlakunya lembaga rechtverwerking berlaku atau diterapkan, sebelumnya tanah sebagai objek sengketa yang dibiarkan sehingga keadaanya ditelantarkan oleh pemiliknya atau oleh orang yang merasa sebagai pemiliknya menurut Pasal 27, 34 dan Pasal 40 UUPA menyebabkan hapusnya hak atas tanah sehingga statusnya Paradigma Hukum Waris Atas Tanah Yang Tidak Mengenal Daluarsa Setelah Terbitnya UUPA

Oleh Andreas J Sinaga 
menjadi tanah negara. Pada saat tanah ditelantarkan oleh pemiliknya maka hak atas tanah itu hapus, keadaan menelantarkan tanah tersebut dianggap sebagai penyerahan hak atas tanahnya secara sukarela, selama kurun waktu tertentu yang ber.akibat kehilangan hak untuk menuntut hak nya kembali.

Dalam hukum adat tidak dapat ditemukan adanya ketentuan secara pasti dan umum seperti KUHPerdata terkait lewat waktu, namun dapat ditemukan secara kasuistis, berdasarkan keadaan-keadaan tertentu dan sifat penguasaanya dengan itikad baik yang berlangsung jangka waktu sekian lama secara terus-menerus sehingga hukum menggangap orang semula yang berhak telah melepaskan haknya. Namun rectherwerking ini berlaku apabila pemilik tanah atau ahli warisnya kesemuanya telah meninggalkan tanahnya selama lebih dari tiga puluh tahun lamanya sehingga tanah tersebut dikuasi oleh orang lain yang telah lama menempati dan mengurus tanahnya.

Menurut Subekti yang menyatakan bahwa dalam hukum adat tidak dikenal suatu ketentuan bahwa suatu hak penuntutan gugur dengan lewatnya suatu jangka waktu tertentu, seperti dalam pasal 1967 KUHPerdata, yang menentukan bahwa semua tuntutan kadaluarsa dengan lewatnya waktu tigapuluh tahun. ${ }^{5}$ Yang dikenal hanyalah suatu pedoman bahwa suatu gugatan tidak dapat diajukan apabila tuntutan didasarkan pada suatu peristiwa yang sudah sekian lamanya berlaku hingga sudah tidak ada lagi sekian lamanya berlaku hingga sudah tidak ada lagi seorang saksipun yang masih hidup yang mengetahui peristiwa itu, sehingga apabila masih ada buktibukti yang cukup maupun saksi-saksi yang masih hidup dan kenal mengenai objek warisan tidak menyebabkan hilangnya hak ahli waris lainnya

\section{Penerapan Hukum Jangka Waktu Hak Menuntut yang Terkandung dalam}

\section{Sistem Kewarisan Masyarakat Adat dalam Putusan Pengadilan}

Peran strategis hakim dalam persepektif sociological Jurisprudence adalah menerapkan hukum tidak melulu dipahami sebagai upaya social control yang bersifat formal dalam menyelesaikan konflik, tetapi sekaligus mendesain penerapan hukum itu sebagai upaya social engineering. Sociological Jurisprudence menjadi bermanfaat bilamana mengenai jangka waktu hak menggugat harta warisan dapat

\footnotetext{
${ }^{5}$ Subekti.2006. Hukum Adat Indonesia dalam Yurisprudensi Mahkamah Agung. Bandung. Alumni. Hal 87

Paradigma Hukum Waris Atas Tanah Yang Tidak Mengenal Daluarsa Setelah Terbitnya UUPA

Oleh Andreas J Sinaga 
dilihat dari kenyataan yang hidup di masyarakat dan dalam hal sumber hukum yang mana yang sering diterapkan untuk memecahkan persoalan jangka waktu hak menggugat dalam sistem kewarisan masyarakat adat, berikut adalah putusanputusan pengadilan yang menolak asas kadaluarsa dalam hukum waris:

\section{a. Putusan Pengadilan Tinggi Kupang No. 95/Pdt/2012/PTK}

Adanya eksepsi yang menyatakan bahwa gugatan telah lewat waktu selama 32 tahun berdasarkan pasal 835 KUHPerdata jo. Pasal 1967 KUHPerdata yang telah kedaluarsa. Majelis Hakim tingkat Banding dalam pertimbangan hukumnya menolak eksepsi gugatan telah kadaluarsa, menurut Majelis Hakim ketentuan pasal 835 KUHPerdata yang mangatakan : tuntutan itu menjadi lewat waktu dengan lewatnya waktu tiga puluh tahun, terhitung dari terbukanya warisan itu, hanyalah berlaku terhadap harta waris yang ditelantarkan dan tidak dapat diberlakukan terhadap harta waris yang dikuasai oleh salah seorang ahli waris dengan tanpa hak. Sedangkan ketentuan pasal 1967 KUHPerdata hanyalah diberlakukan terhadap kewajiban pemenuhan prestasi kebendaan dan perorangan dalam suatu perikatan dan tidak berlaku didalam hukum kewarisan yang bersifat tuntutan atas hak waris, itulah sebabnya pasal tersebut diletakkan dalam Bab tentang "Lewat Waktu Sebagai Suatu Alasan untuk Dibebaskan dari Suatu Kewajiban”. Majelis Hakim mengikuti pedoman Yurisprudensi MA No. 7 K/Sip/1973 tanggal 27 Pebruari 1975 yang menyatakan "Tidak ada batas waktu dalam menggugat harta warisan" dan Yurisprudensi MA No. 457 K/Sip/1974 tanggal 9 September 1976 yang menyatakan "Lampau waktu saja tidak menyebabkan hapusnya sesuatu hak, tetapi harus dipenuhi syarat yang lain".

\section{b. Putusan Mahkamah Agung No. 1482 K/Pdt/2012}

Mahkamah Agung memperbaiki pertimbangan hukum Judex Facti penerapan ketentuan Pasal 835 KUHPerdata juga bertentangan dengan ketentuan Yurisprudensi tetap Mahkamah Agung RI No.157 K/Sip/1975 tertanggal 18 September 1976 dalam perkara antara Mohamad Nazir gelar Malin Marajo melawan Manan gelar Rajo Indo yang menyatakan "Hak Penggugat untuk menggunakan tanahnya yang sudah lama dikuasai oleh Tergugat tidak terkena daluarsa"

Paradigma Hukum Waris Atas Tanah Yang Tidak Mengenal Daluarsa Setelah Terbitnya UUPA

Oleh Andreas J Sinaga 


\section{c. Putusan Mahkamah Agung No. 312/K/AG/1997}

Mahkamah Agung menolak dalil mengenai asas kedaluarsa dalam hukum waris yang pada intinya kaidah hukumnya menyatakan "Ketentuan Verjaring atau kadaluarsa yang diatur dalam Pasal 835 Jo. 1967 KUHPerdata, tidak dapat diberlakukan terhadap orang bumiputra, karena dalam Hukum Waris tidak dianut asas kadaluarsa dalam gugatan harta warisan yang belum dilakukan pembagian kepada para ahli warisnya.

\section{d. Putusan Pengadilan Negeri Jakarta Timur No.555/Pdt.G/2018}

Dalam Jawaban Para Tergugat, eksepsinya yang menyatakan gugatan yang diajukan oleh Para Penggugat adalah gugatan yang kadaluarsa verjaring sehingga secara hukum sudah selayaknya untuk dikesampingkan seluruhnya berdasarkan ketentuan Pasal 1967 KUHPer adalah suatu keharusan dwinged recht. Para Penggugat baru mendaftarkan gugatannya kepada Kepaniteraan Pengadilan Negeri Jakarta Timur pada tanggal 04 Desember 2018, artinya setelah lewat waktu 46 tahun gugatan Para Penggugat harus dinyatakan ditolak untuk seluruhnya karena telah melepaskan hak yang dimilikinya rechtverwerking. Namun dalam pertimbangannya, Majelis Hakim Pengadilan Negeri Jakarta Timur menyatakan bahwa dalam hukum adat dimana tanah adat tidak mengenal kadaluarsa, dengan demikian karena objek sengketa berasal dari tanah adat maka tidak dikebal daluarsa. Oleh sebab itu eksepsi Para Tergugat ditolak oleh Majelis Hakim.

\section{e. Putusan Pengadilan Negeri Surabaya No. 217/Pdt.G/2017/PN.SBY}

Dalam Jawaban Tergugat, eksepsi mengenai lampau waktu Tergugat menyatakan bahwa Tergugat telah menguasai tanah sengketa dan mendirikan bangunan diatasnya sudah 32 tahun terlampaui barulah Penggugat menggugat.Namun dalam pertimbangan Majelis Hakim Pengadilan Negeri Surabaya mengenai eksepsi lampaunya waktu, Majelis Hakim menimbang bahwa gugatan Penggugat tidak daluarsa karena hukum adat tidak mengenal daluarsa "hukum adat tidak mengenal daluarsa, maka gugatan Penggugat masih tetap dapat diterima dan diperiksa seta diputuskan seperti biasa" (MA 22 Desember 1971 No.802K/Sip/1971. Yurisprudensi Jawa Barat 1969-1972 dan "dalam hukum adat dengan lewatnya waktu saja hak milik atas tanah tidak hapus"(MA 19 Desember 1973 No. 916K/Sip/1973). Majelis hakim menimbang Pasal 855 KUHPer Paradigma Hukum Waris Atas Tanah Yang Tidak Mengenal Daluarsa Setelah Terbitnya UUPA

Oleh Andreas J Sinaga 
mengenai suatu gugatan menjadi kadaluarsa dalam waktu 30 tahun tidak diberlakukan oleh sebab peraturan Pasal 835 KUHPer berlaku bagi orang timur asing sedangkan untuk orang bumuputera (termasuk Penggugat) berlaku hukum adat. Majelis Hakim berpendapat bahwa gugatan Penggugat tidak daluarsa, sehingga eksepsi Tergugat ditolak.

\section{f. Putusan PN Jember No. 118/Pdt.G/2019/PN.JR jo Putusan Pengadilan} Tinggi Surabaya No. 438/Pdt/2010/PT.SBY

Dalam jawaban Tergugat mengenai kadaluarsa yang menyatakan Para Penggugat tidak berhak mengajukan gugatan perkara in casu dengan memperhatikan asas kadaluarasa suatu gugatan karena sejak tahun 1978, Mat P. Nipa menguasasi tanah dengan identitas C.No.1177, Persil No.18, Klas D III, Luas 549 terletak di Lingkungan Perbal menebus ke B Suha, dimana B Tuki telah menggadaikannya ke B Suha. Majelis Pengadilan Negeri Jember dalam pertimbangannya bahwa status objek sengketa adalah merupakan harta bawaan dan belum dibagi waris kepada para ahli warisnya maka perkara in casu tidak termasuk kedalam kadaluarsa.

\section{KESIMPULAN}

Pemeliharaan/Penguasaan objek warisan yang dikuasai, ditempati maupun diolah orang salah satu ahliwaris bukan menyebabkan beralihnya kepemilikan dan juga bukan menjadi leluasa atau sewenang-wenang ahli waris yang mengusai sementara objek warisan tersebut bahkan bukan menyebabkan ahli warisnya lainnya tidak/bukan menelantarkan atau tidak memelihara objek warisan yang belum terbagi tersebut. Paradigma Hukum waris tanah dalam UUPA tidak mengenal lembaga Verjaring (daluarsa memperoleh) seperti yang diatur dalam KUHPerdata, melainkan menggunakan lembaga rechtverwerking (daluarsa melepaskan hak). Lembaga Rechtverwerking masih diterapkan dalam hal penguasaan tanah yang telah ditelantarkan namun bukan untuk tanah warisan belum terbagi dan/atau yang dikuasai oleh salah satu pihak. Apabila seseorang hendak melakukan gugatan terhadap tergugat yang telah mempunyai sertifikat telah lewat 5 tahun sesuai ketentuan Pasal 32 ayat 2 dari PP No. 24 Tahun 1997 maka penggugat tidak menggugat untuk pembatalan sertifikat ke Pengadilan Tata Usaha

Paradigma Hukum Waris Atas Tanah Yang Tidak Mengenal Daluarsa Setelah Terbitnya UUPA

Oleh Andreas J Sinaga 
Negara melainkan berdasarkan sengketa waris maupun sengketa kepemilikan hak agar sertifikatnya dinyatakan tidak sah dan tidak berlaku.

Penerapan hukum jangka waktu hak menuntut yang terkandung dalam sistem kewarisan masyarakat adat dalam putusan pengadilana dapat dilihat dalam putusanputusan: Putusan Pengadilan Tinggi Kupang No. 95/Pdt/2012/PTK; Putusan Mahkamah Agung No. 1482 K/Pdt/2012; Putusan Mahkamah Agung No. 312/K/AG/1997; Putusan Pengadilan Negeri Jakarta Timur No.555/Pdt.G/2018; Putusan PN Jember No. 118/Pdt.G/2019/PN.JR jo Putusan Pengadilan Tinggi Surabaya No. 438/Pdt/2010/PT.SBY; Putusan PN Surabaya No. 217/Pdt.G/2017/PN.SBY. Kesemuanya mengikuti pedoman Yurisprudensi MA No. 7 K/Sip/1973 tanggal 27 Pebruari 1975 yang menyatakan "Tidak ada batas waktu dalam menggugat harta warisan” dan Yurisprudensi MA No. 457 K/Sip/1974 tanggal 9 September 1976 yang menyatakan "Lampau waktu saja tidak menyebabkan hapusnya sesuatu hak, tetapi harus dipenuhi syarat yang lain”.

\section{DAFTAR PUSTAKA}

Kartohadiprodjo, Sudiman, 1971, Hukum Nasional, Beberapa Catatan, Binacipta, Bandung

Rasjidi, Lili dan Rasjidi, Ira, 2007, Dasar-Dasar Filsafat dan Teori Hukum, PT. Citra Aditya Bakti, Bandung

Rato, Dominikus, 2015, Hukum Perkawinan dan Waris Adat di Indonesia, Laksbang, Yogyakarta

Soedarso, Hukum Adat Waris, didalam buku Eksistensi Pengadilan Adat Dalam Sistem Peradilan Adat Di Indonesia, Herowati Poesok et all, 2014, LaksBang Justitia, Surabaya

Soekanto, Soerjono, 2007, Pokok-Pokok Sosiologi Hukum, Raja Grafindo Persada, Jakarta

Subekti, 2006. Hukum Adat Indonesia dalam Yurisprudensi Mahkamah Agung, Bandung, Alumni

Supomo, 1967, Bab-bab tentang Hukum Adat, Alumni, Bandung

Warrasih, Esmish, 2005, Pranata Hukum Sebuah Telaah Sosiologis Suryanduru, Semarang

Wulansari, Dewi, 2014, Hukum Adat Indonesia Suatu Pengantar, Refika Aditama, Bandung

Undang-Undang Dasar 1945

Kitab Undang-Undang Hukum Perdata

Undang-Undang Nomor 5 Tahun 1960 Tentang Peraturan Dasar Pokok-Pokok Agraria

PP Nomor 24 tahun 1997 Tentang Pendaftaran Tanah

Putusan Mahkamah Agung No. 1482 K/Pdt/2012

Paradigma Hukum Waris Atas Tanah Yang Tidak Mengenal Daluarsa Setelah Terbitnya UUPA

Oleh Andreas J Sinaga 
Putusan Mahkamah Agung No. 312/K/AG/1997

Putusan Pengadilan Tinggi Kupang No. 95/Pdt/2012/PTK

Putusan PN Jember No. 118/Pdt.G/2019/PN.JR jo Putusan Pengadilan Tinggi Surabaya No. 438/Pdt/2010/PT.SBY

Putusan Pengadilan Negeri Jakarta Timur No.555/Pdt.G/2018

Putusan Pengadilan Negeri Surabaya No. 217/Pdt.G/2017/PN.SBY

Paradigma Hukum Waris Atas Tanah Yang Tidak Mengenal Daluarsa Setelah Terbitnya UUPA

Oleh Andreas J Sinaga 